\title{
Biocatalysis using lipase encapsulated in microemulsion-based organogels in supercritical carbon dioxide
}

\author{
Christian Blattner ${ }^{\mathrm{a}}$, Maria Zoumpanioti ${ }^{\mathrm{b}}$, Jürgen Kröner $^{\mathrm{a}}$, Georg Schmeer ${ }^{\mathrm{a}}$, \\ Aristotelis Xenakis ${ }^{\mathrm{b}, *}$, Werner Kunz ${ }^{\mathrm{a}, *}$ \\ ${ }^{a}$ Institut für Physikalische und Theoretische Chemie, Universität Regensburg, D-93040 Regensburg, Germany \\ ${ }^{\mathrm{b}}$ Institute of Biological Research and Biotechnology, The National Hellenic Research Foundation, Athens, Greece
}

Received 1 November 2004; received in revised form 10 May 2005; accepted 15 June 2005

\begin{abstract}
Lipases from Candida antarctica and Mucor miehei were encapsulated in lecithin water-in-oil (w/o) microemulsion-based organogels (MBG). These gels were formulated with either hydroxypropylmethyl cellulose (HPMC) or gelatin. The esterification of lauric acid and 1-propanol catalyzed by these MBGs was examined in supercritical carbon dioxide $\left(\mathrm{scCO}_{2} ; 35^{\circ} \mathrm{C}, 110\right.$ bar $)$ as solvent for the substrates. The results were compared to those obtained with the reference substrate solvent isooctane. It turned out that the initial rates of this model reaction in $\mathrm{scCO}_{2}$ were higher than those observed in the reference system. Various parameters affecting the biocatalysis such as pressure, alcohol and acid chain length, and gel composition were investigated. Kinetic studies showed that the ester synthesis catalyzed by the immobilized $C$. antarctica lipase occurs via a Ping Pong Bi Bi mechanism in which only inhibition by excess of alcohol was identified. Values of all kinetic parameters were determined. In addition, experiments on the reusability of these gels in $\mathrm{scCO}_{2}$ were carried out and the state of water within the organogel was examined with the help of differential scanning calorimetry. The present study shows that biocatalysis using MBGs in $\mathrm{scCO}_{2}$ is a promising alternative to other bioconversion processes.
\end{abstract}

(C) 2005 Elsevier B.V. All rights reserved.

Keywords: Microemulsion; Organogels; Lipases; Enzymatic reaction; Supercritical $\mathrm{CO}_{2}$

\section{Introduction}

Increasing concerns regarding toxicity and environmental compatibility of industrial processes have resulted in intensified efforts in "sustainable development" and "green chemistry". These terms describe a new field in chemistry, which is based on waste minimization through reaction design, on energy efficiency, on non-hazardous raw materials, solvents or products, on inherently safe chemical processes, and on renewable feedstocks. Among other strategies for achieving these aims, the research on catalytic reaction processes and sustainable solvents is of special interest $[1,2]$.

\footnotetext{
* Corresponding authors.

E-mail addresses: arisx @eie.gr (A. Xenakis); Werner.Kunz@chemie.uni-regensburg.de (W. Kunz)
}

In the field of catalysis, the use of enzymes in organic synthesis and in non-conventional solvents has become an interesting alternative to conventional chemical methods [3,4]. One of the most intensively studied methods has been the technique of solubilizing enzymes in hydrated reverse micelles or water-in-oil microemulsions where they may retain their catalytic ability. Of particular interest is the case of lipases since apart from their physiological function to hydrolyze triglycerides they may also catalyze under specific conditions biotechnologically interesting synthetic reactions involving fatty acids [5].

Due to problems in product isolation and enzyme reuse in microemulsion systems, the use of microemulsion-based organogels (MBGs) has attracted attention. MBGs are rigid and stable in various non-polar organic solvents and may therefore be used for biotransformations in organic media. The gel matrix formed by a gelling agent, such as gelatin, fully retains the surfactant, water and enzyme components and can 
be handled as an immobilized biocatalyst that facilitates the diffusion of non-polar substrates and products. The preparation of MBGs was first reported in 1986 [6-8] and subsequent spectroscopic investigations $[9,10]$ have shown that the microemulsion structure is well preserved in the network of the gels, which are believed to contain a more or less bicontinuous phase that may co-exist with conventional w/o microemulsion droplets. MBGs containing immobilized lipase were applied for the preparative scale synthesis of miscellaneous esters and both regio- and stereoselectivity have been observed [11-21].

Apart from gelatin, biopolymers such as agar, kcarrageenan and cellulose have been reported to form MBGs as an enzyme immobilization matrix [22-24]. These gels overcome the restrictions to which the gelatin-based gels are subject with regard to biocatalytic applications, as they provide good mechanical and thermal stability and show high resistance to hydrophilic environments.

In parallel, liquid or supercritical carbon dioxide $\left(\mathrm{scCO}_{2}\right)$ has emerged as perhaps the most promising "green" solvent (apart from water): carbon dioxide is toxicologically harmless, not inflammable, readily available and inexpensive. Besides, it exhibits a moderate critical point $\left(\Theta_{\mathrm{c}}=30.98^{\circ} \mathrm{C}\right.$, $p_{\mathrm{c}}=73.773$ bar [25]) and tunable solvent and solvation properties by simple control of pressure and temperature [26].

The low critical temperature makes $\mathrm{scCO}_{2}$ an ideal solvent for heat-sensitive substances such as biocatalysts. Consequently, enzymatic reactions in $\mathrm{scCO}_{2}$ have been under investigation since 1985, when Randolph et al. were the first to conduct an enzymatic reaction in $\mathrm{scCO}_{2}$ using alkaline phosphatase [27]. Apart from a few reported enzymatic reactions in microemulsions formulated with special $\mathrm{CO}_{2}$-philic surfactants [28-30], these studies were predominantly performed with solid (free) or conventionally immobilized enzymes. Reviews about systems studied so far are given by Perrut [31], Hartmann et al. [32] and Oakes et al. [33].

The present work is a first attempt to join the two research directions - MBGs and $\mathrm{scCO}_{2}$ - aiming at replacing any external organic solvent, e.g. isooctane, used in the conventional biocatalytic process by the harmless $\mathrm{scCO}_{2}$. For this purpose, lipases were encapsulated in lecithin water-in-oil (w/o) microemulsion-based organogels which were formulated with hydroxypropylmethyl cellulose (HPMC). The effect of various parameters, like pressure, mass fraction of biopolymer, alcohol and carboxylic acid chain length, was studied in $\mathrm{scCO}_{2}$. Results are discussed with reference to experiments performed with the same MBGs in isooctane as solvent. In addition, a kinetic study of MBG encapsulated Candida antarctica lipase in $\mathrm{scCO}_{2}$, based on a simple model esterification reaction, was undertaken to clarify the reaction mechanism and to determine the apparent kinetic constants. To characterize the gels in more details differential scanning calorimetry (DSC) measurements were also carried out.

\section{Experimental}

\subsection{Materials}

Lipases from $C$. antarctica and Mucor miehei, respectively, and bis-(2-ethylhexyl)sulfosuccinate (AOT; BioChemika MicroSelect) were supplied by Fluka. Lipase B from $C$. antarctica $(\mathrm{CaL})$ had a specific activity of $9.2 \mathrm{U} \mathrm{mg}^{-1}$ (1 $\mathrm{U}$ corresponds to the amount of enzyme which liberates $1 \mathrm{mmol}$ butyric acid per min at $\mathrm{pH} 8.0$ and $40^{\circ} \mathrm{C}$ using tributyrine as substrate), whereas the M. miehei lipase $(\mathrm{MmL})$ had a specific activity of $242 \mathrm{U} \mathrm{mg}^{-1}$ (1 U corresponds to the amount of enzyme which liberates $1 \mathrm{mmol}$ oleic acid per min at $\mathrm{pH} 8.0$ and $40{ }^{\circ} \mathrm{C}$ using trioleine as substrate). Lecithin, containing approximately $40 \%$ (TLC) phosphatidylcholine, HPMC $(3500-5600 \mathrm{cP})$ and lauric acid $(\geq 99 \%)$ were purchased from Sigma. All other materials were at least reagent grade except for gelatin (Merck; powder food grade) and $n$-hexane (extra pure). Millipore Milli-Q water was used for the preparation of gels and buffer solution.

\subsection{Preparation of microemulsions}

Lecithin microemulsions for HPMC-based gels were prepared by adding appropriate amounts of lipase in $200 \mathrm{mM}$ Tris/HCl pH 7.5 buffer to a solution of 5.0\% (v/v) 1-propanol (2-propanol) and $4.8 \%(\mathrm{w} / \mathrm{w})$ lecithin (used as received) in isooctane. AOT microemulsions were prepared by adding appropriate amounts of lipase in $200 \mathrm{mM}$ Tris/ $\mathrm{HCl} \mathrm{pH} 7.5$ buffer to a $200 \mathrm{mM}$ AOT solution in isooctane. The final water content of the system was 3.5\% (v/v) yielding a molar hydration ratio $w_{0}=\left[\mathrm{H}_{2} \mathrm{O}\right] /[\mathrm{AOT}]$ of approximately 10 .

In the case of lecithin microemulsions for gelatin gels appropriate amounts of buffer containing lipase were added to a solution of $22.2 \%(\mathrm{w} / \mathrm{w}$ ) lecithin in isooctane containing $32 \%$ $(\mathrm{v} / \mathrm{v}) 1$-propanol and $26.5 \%(\mathrm{v} / \mathrm{v})$ water. Respective AOT microemulsions were prepared by addition of lipase containing buffer to a solution of $17.8 \%(\mathrm{w} / \mathrm{w})$ AOT in $n$-hexane containing $7.3 \%(\mathrm{v} / \mathrm{v})$ water.

\subsection{Preparations of gels}

The MBGs were prepared by introducing appropriate amounts of microemulsion containing lipase to a second solution of polymer in water. In the case of HPMC gels, $1.02 \mathrm{~mL}$ of lecithin or AOT microemulsion containing $1.20 \mathrm{mg} \mathrm{CaL}$ or $0.22 \mathrm{mg} \mathrm{MmL}$ was gelled with $1.0 \mathrm{~g}$ HPMC and $2.0 \mathrm{~mL}$ of water at room temperature. The gelatin gels were prepared by gelling $4.0 \mathrm{~mL}$ AOT or $3.6 \mathrm{~mL}$ lecithin microemulsion with $1.4 \mathrm{~g}$ gelatin and $1.8 \mathrm{~mL}$ of water. The gelatin-water mixture was preheated to $55^{\circ} \mathrm{C}$, stirred until homogeneous and then allowed to cool. Organogels were formed by addition of the microemulsion part at $35^{\circ} \mathrm{C}$. Data concerning the exact amounts of enzyme in the respective gelatin-based MBGs is given in Table 1. 
Table 1

Esterification of $103 \mathrm{mM}$ lauric acid and $207 \mathrm{mM}$ 1-propanol. Survey of the tests on enzyme activity in MBGs with $\mathrm{CO}_{2}$ as solvent: \% conversion of lauric acid to 1-propyl-laurate. Reaction time: $3 \mathrm{~h}$ unless otherwise stated

\begin{tabular}{llllc}
\hline Polymer & Surfactant & Lipase & $m_{\text {Lipase }}(\mathrm{mg})$ & \%of conversion \\
\hline HPMC $^{\mathrm{a}}$ & \multirow{2}{*}{ Lecithin } & $\mathrm{CaL}$ & 1.20 & 36.5 \\
& & $\mathrm{MmL}$ & 0.22 & 11.5 \\
& $\mathrm{AOT}$ & $\mathrm{CaL}$ & 1.20 & 10.7 \\
& & $\mathrm{MmL}$ & 0.22 & 1.6 \\
\multirow{3}{*}{ Gelatin } & \multirow{2}{*}{ Lecithin } & \\
& & $\mathrm{CaL}$ & 0.90 & 1.8 \\
& $\mathrm{AOT}$ & $\mathrm{MmL}$ & 0.17 & 2.2 \\
& & $\mathrm{CaL}^{\mathrm{b}}$ & 7.19 & 17.0 \\
& & $\mathrm{MmL}^{\mathrm{c}}$ & 1.32 & 9.0 \\
& & $\mathrm{MmL}^{\mathrm{d}}$ & 1.39 & 36.8 \\
\hline
\end{tabular}

a $35^{\circ} \mathrm{C}, 110$ bar. ${ }^{\text {b }} 25^{\circ} \mathrm{C}, 150$ bar. $\quad{ }^{\mathrm{c}} 25^{\circ} \mathrm{C}, 175$ bar. ${ }^{\mathrm{d}} 25.2^{\circ} \mathrm{C}$, 130 bar, gelation with $4.6 \mathrm{~mL}$ AOT microemulsion, reaction time: $7 \mathrm{~h}$.

\subsection{High-pressure cell}

An outline of the high-pressure apparatus is given in Fig. 1. Experiments were performed with a stainless steel view cell with fixed volume ( $32.1 \mathrm{~mL}$ total volume) with four $6 \mathrm{mM}$ diameter sapphire windows (SITEC-Sieber Engineering) permitting visual observation. The cell assembly was placed in an air thermostat allowing temperature control to $0.1 \mathrm{~K}$. Additionally, the cell temperature was controlled to within less than $0.1 \mathrm{~K}$ at constant pressure via a thermostating jacket by a cryostat, and the temperature inside the cell was monitored with a Pt100 resistance thermometer (SITEC-Sieber
Engineering). Pressure was generated with a dosing pump (Milroyal D, Dosapro Milton Roy) and electronically measured with pressure transducers (ED 517; Bourdon-Haenni). Both the air thermostat chamber and the pressurizing assembly were computer controlled.

Furthermore, the apparatus was additionally equipped with a Gilson M305 HPLC pump and a Rheodyne injection valve for the injection of substrates by pumping fresh carbon dioxide into the cell and thus reaching the adjusted reaction pressure.

\subsection{Lipase-catalyzed reactions}

The freshly prepared gels were loaded into the highpressure cell, which was then sealed. The temperature was adjusted to about $0.8 \mathrm{~K}$ below the final temperature as pressurizing results in a temperature increase. After increasing the pressure by feeding the cell with $\mathrm{CO}_{2}$, the reactions were started by injecting appropriate amounts of lauric acid and 1-propanol solubilized in small amounts of isooctane. The solutions were not stirred during reaction. Analysis of the reactions was done by GC (HP 6890 Series; HP-5 capillary column) after depressurizing and sample recovery. For the HPMC gels the reaction temperature was $35^{\circ} \mathrm{C}$, whereas in the case of the gelatin gels a temperature of $25^{\circ} \mathrm{C}$ was chosen (liquid $\mathrm{CO}_{2}$ ).

Kinetic measurements were carried out batchwise: sets of identical samples with freshly prepared, new gels were sealed in the high-pressure cell and the reactions were stopped at cer-

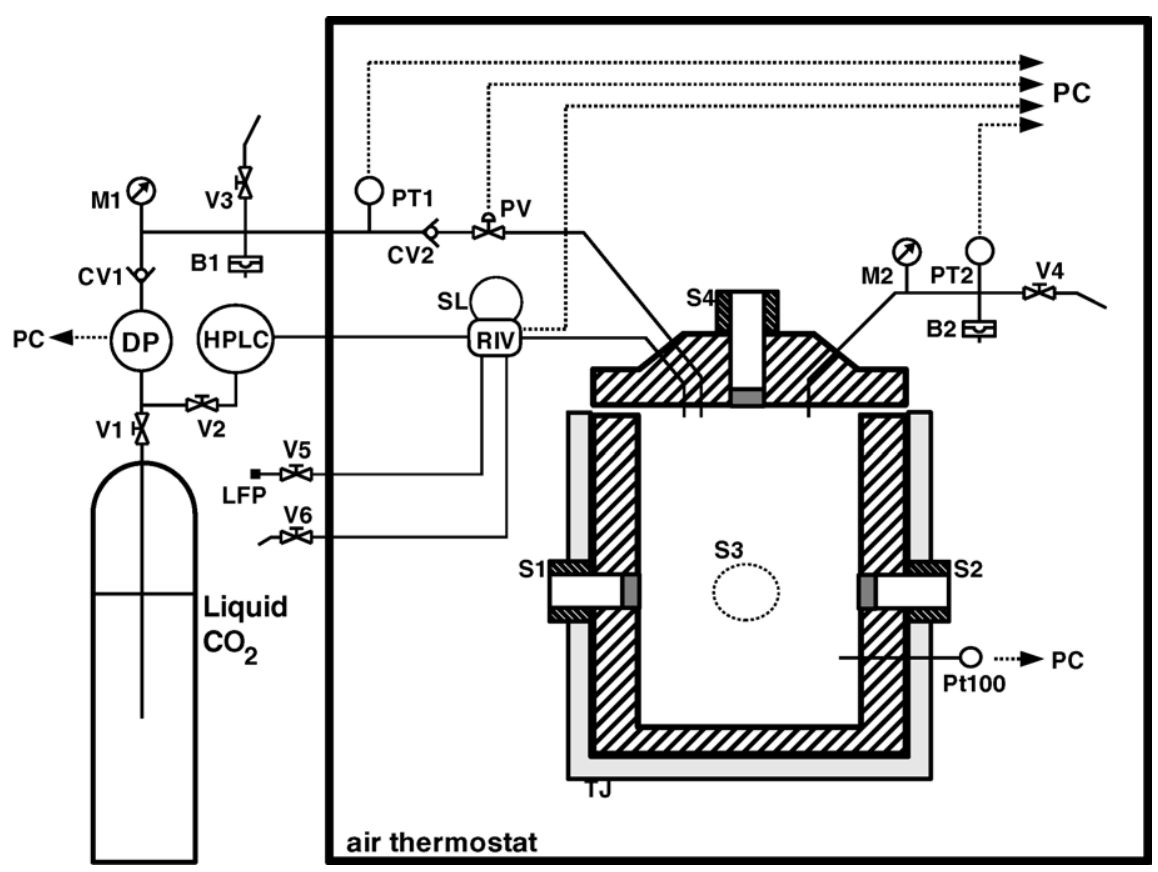

Fig. 1. Outline of the high-pressure apparatus. DP: dosing pump. V1-V6: high-pressure valve; CV1-CV2: check valve; PV: air operated valve; M1-M2: analogue manometer; PT1-PT2: pressure transducer; Pt100: Pt resistance thermometer; S1-S4: sapphire window; HPLC: Gilson M305 HPLC pump; RIV: Rheodyne injection valve; SL: sample loop; LFP: loop filling port; TJ: additional cell thermostatting; PC: computer. 
tain predefined time intervals. Reproducibility tests showed that all measured conversions were reproducible within $\pm 2 \%$, most of them even within less than $\pm 1 \%$.

For a reference system isooctane was chosen as the external conventional organic solvent. In this case, the lipase containing MBGs were put into vials where the solvent containing the substrates was added. The reactions took place at $35^{\circ} \mathrm{C}$ and ambient pressure as described elsewhere [24].

\subsection{Determination of kinetic parameters}

Parametric identification of maximum velocity, Michaelis-Menten constants and inhibition constants was done from the equation for the initial reaction rate in absence of product. The program used for identification was based on a Levenberg-Marquardt algorithm.

\subsection{DSC measurements}

Differential scanning calorimetry (DSC) measurements on gels of different composition were performed using a Setaram Micro DSC III. Phase transition of water in these gels was studied between -20 and $25^{\circ} \mathrm{C}$ with a scan rate of $0.5 \mathrm{~K} \mathrm{~min}^{-1}$.

\subsection{Biocatalyst reuse}

In order to determine the stability of the CaL immobilized in the HPMC organogels with lecithin microemulsion, the gels were reused in consecutive independent batches in $\mathrm{scCO}_{2}$. Each batch reaction was continued for $3 \mathrm{~h}$ at $35^{\circ} \mathrm{C}$. The total volume of the batch was $32.1 \mathrm{~mL}$ in each case. After each run, the organogels containing lipase were washed twice with $10 \mathrm{~mL}$ isooctane and a new catalytic reaction was started in $\mathrm{scCO}_{2}$ as described before. The same series of experiments was also performed in the reference system isooctane at $35^{\circ} \mathrm{C}$ and with $32.1 \mathrm{~mL}$ total volume.

\section{Results}

\subsection{Choice of system}

In the present work, the ability of HPMC as well as gelatin organogels based on both AOT as well as lecithin microemulsions to catalyze esterification reactions in $\mathrm{scCO}_{2}$ was investigated. As a first reaction the esterification between lauric acid and 1-propanol was chosen. The preliminary tests were performed with gel compositions similar to those published recently [22-24].

It was observed that the carbon dioxide phase above the HPMC gels remained transparent, whereas in the case of the gelatin gels turbidity appeared when the amount of microemulsion in the gel exceeded $55 \%(\mathrm{w} / \mathrm{w})$. After injection of the substrate solution the carbon dioxide phase becomes turbid independently of the microemulsion content of the gels. This is observed for both gelatin and HPMC gels.

With carbon dioxide as external solvent both enzymes were catalytically active in MBGs based on either HPMC or gelatin formulated with either AOT or lecithin microemulsions (cf. Table 1). It should be noticed that the experiments with the gelatin MBGs were carried out in liquid $\mathrm{CO}_{2}$ at $25^{\circ} \mathrm{C}$ because they are molten at $35^{\circ} \mathrm{C}$. After having accomplished the reactions in the $\mathrm{CO}_{2}$ environment, all gels were tested in a subsequent esterification reaction with isooctane as external solvent according to the conventional procedure [24]. These tests showed that the catalytic activity of the enzyme was maintained in all gels excluding any deleterious effect of $\mathrm{CO}_{2}$ on the lipase. According to the results shown in Table 1, the most appropriate system is the HPMC organogel formed with lecithin microemulsion and $\mathrm{CaL}$ as catalyst. Consequently, the focus was set on this particular type of gel.

Furthermore, esterification reactions with different alcohols such as geraniol or nerol, or different acids such as the phenolic acids $p$-hydroxyphenylacetic acid (HPA) and $p$-hydroxyphenylpropionic acid (HPP) were conducted in $\mathrm{ScCO}_{2}$. In the case of geraniol and nerol, 1-propanol in the microemulsion was replaced by 2-propanol in order to avoid substrate competition. The conversions observed for the esterification of these alcohols with lauric acid where not as high as those obtained for the synthesis of 1-propyl-laurate. In the case of phenolic acid esterification with 1-propanol, following the reaction was not possible, as neither acids nor esters could be detected after sampling.

Various esters, such as butyl laurate, vinyl acetate, ethyl acetate, ethyl acetoacetate and ethyl crotonate, were tested for transesterification with 1-propanol. However, as the latter two esters did not show any conversion in isooctane as solvent within $3 \mathrm{~h}$ and the reaction of ethyl acetate was very slow, transesterification reactions in $\mathrm{scCO}_{2}$ were just performed with butyl laurate $(88 \mathrm{mM}$ butyl laurate; $207 \mathrm{mM}$ 1-propanol; 110 bar; $35^{\circ} \mathrm{C}$; reaction time: $3 \mathrm{~h}$; conversion: $8.9 \%$ ) and vinyl acetate $(202 \mathrm{mM}$ vinyl acetate; $207 \mathrm{mM}$ 1-propanol; 110 bar; $35^{\circ} \mathrm{C}$; reaction time: $3 \mathrm{~h}$; conversion: $28.2 \%)$.

\subsection{Effect of pressure}

Fig. 2 shows the effect of pressure on the reaction profiles of the esterification of lauric acid with 1-propanol and thus on the initial reaction velocities in $\mathrm{scCO}_{2}$ at $35^{\circ} \mathrm{C}$. The initial rate decreases with increasing pressure from 110 to 200 bar, but a further raise of pressure does not affect the reaction velocity anymore.

\subsection{Kinetic analysis}

Fig. 3 shows the initial reaction profile of the esterification of $103 \mathrm{mM}$ lauric acid with various concentrations of 1propanol catalyzed by CaL immobilized in a HPMC-lecithin 


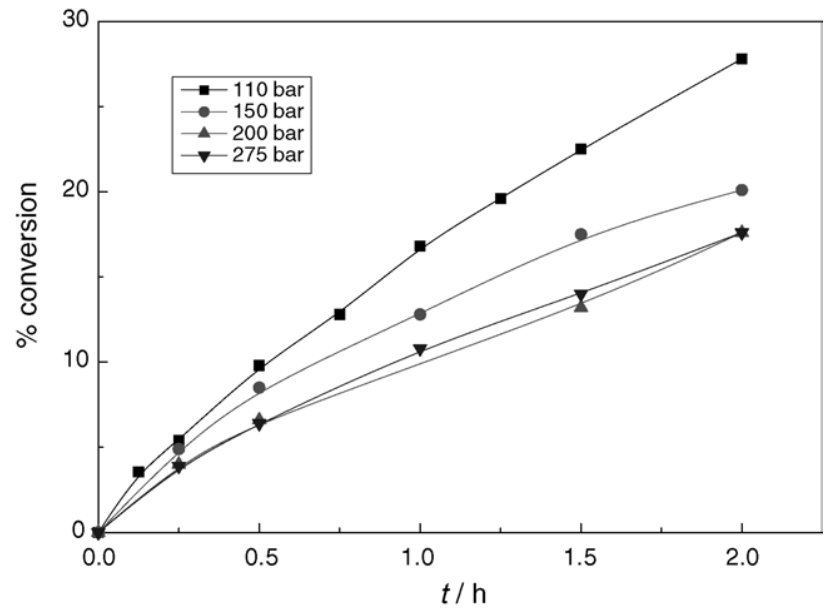

Fig. 2. Influence of pressure on the reaction profiles of the esterification of $103 \mathrm{mM}$ lauric acid and $207 \mathrm{mM}$ 1-propanol catalyzed by CaL immobilized in a HPMC-lecithin MBG containing $1.20 \mathrm{mg}$ enzyme at $35^{\circ} \mathrm{C}$ in $\mathrm{scCO}_{2}$.

MBG containing $1.20 \mathrm{mg}$ enzyme at $35^{\circ} \mathrm{C}$ and 110 bar in $\mathrm{scCO}_{2}$. Typical profiles are observed with the produced amounts of ester increasing upon increase of the alcohol concentration up to $207 \mathrm{mM}$. A further increase of the 1-propanol concentration results in a decrease of the initial rate. The same can be seen in Fig. 4 which displays the initial rate as a function of the alcohol concentration at different constant lauric acid concentrations. Again, too high alcohol concentrations lead to an inhibitory effect.

A Lineweaver-Burk double reciprocal plot of the initial rate versus the 1-propanol concentration in the non-inhibitory alcohol concentration range is shown in Fig. 5. As can be seen, a set of parallel lines is obtained. Furthermore, Fig. 6 shows the double reciprocal plot of the initial velocity as a function of the lauric acid concentration. Again, the plots appear to be parallel for alcohol concentrations up to $207 \mathrm{mM}$.

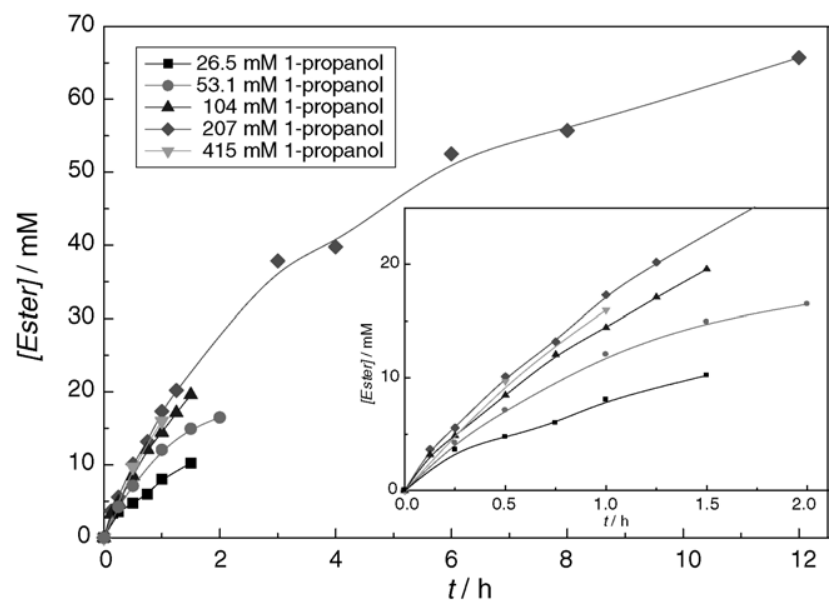

Fig. 3. Reaction profile of the esterification of $103 \mathrm{mM}$ lauric acid and 1propanol catalyzed by CaL immobilized in a HPMC-lecithin MBG containing $1.20 \mathrm{mg}$ enzyme at $35^{\circ} \mathrm{C}$ and $110 \mathrm{bar}$ in $\mathrm{scCO}_{2}$. The insert represents a magnification of the first $2 \mathrm{~h}$.

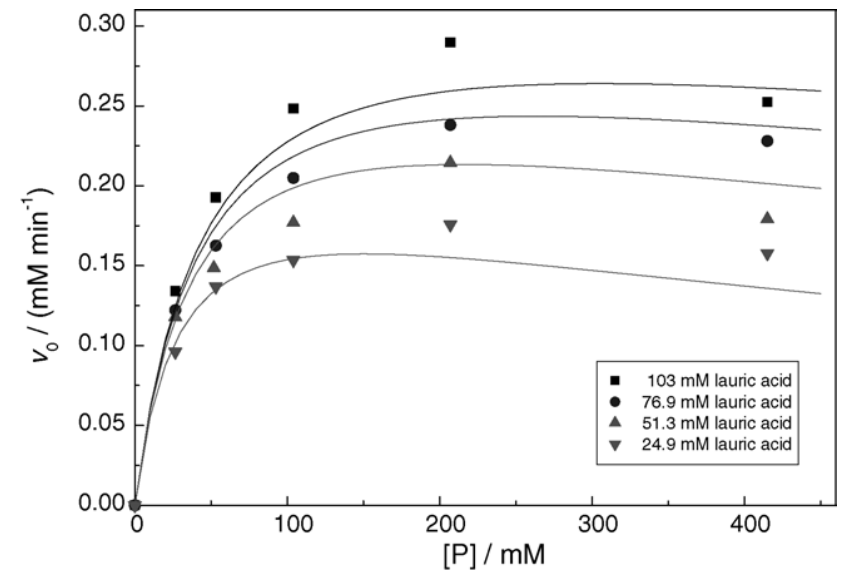

Fig. 4. Effect of the 1-propanol concentration, [P], on the initial reaction velocity, $v_{0}$. Esterification of 1-propanol by lauric acid at different fixed concentrations of lauric acid in $\mathrm{scCO}_{2}$ at 110 bar and $35^{\circ} \mathrm{C}$. Lines calculated according to the kinetic model (cf. Eq. (1) and Table 3).

\subsection{Effect of substrate chain length}

The influence of the alcohol and acid carbon chain length was studied in both $\mathrm{scCO}_{2}$ and the reference isooctane system. For the determination of the changes in the reaction rate in $\mathrm{scCO}_{2}$ the conversions after $3 \mathrm{~h}$ were chosen. Since the amount of produced ester is supposed to increase more or less linearly in this time interval, the differences in the conversion after $3 \mathrm{~h}$ are assumed to correlate to different initial rates. With regard to the observed reproducibilities in $\mathrm{scCO}_{2}$ the chosen time interval of $3 \mathrm{~h}$ is considered long enough for secure differentiation of the results above possible error. For the experiments in the reference system, the initial rates for the different alcohols and acids were determined from the initial slope of the reaction profile.

The effect of alcohol chain length was studied by following the esterification of lauric acid with a series of $n$ -

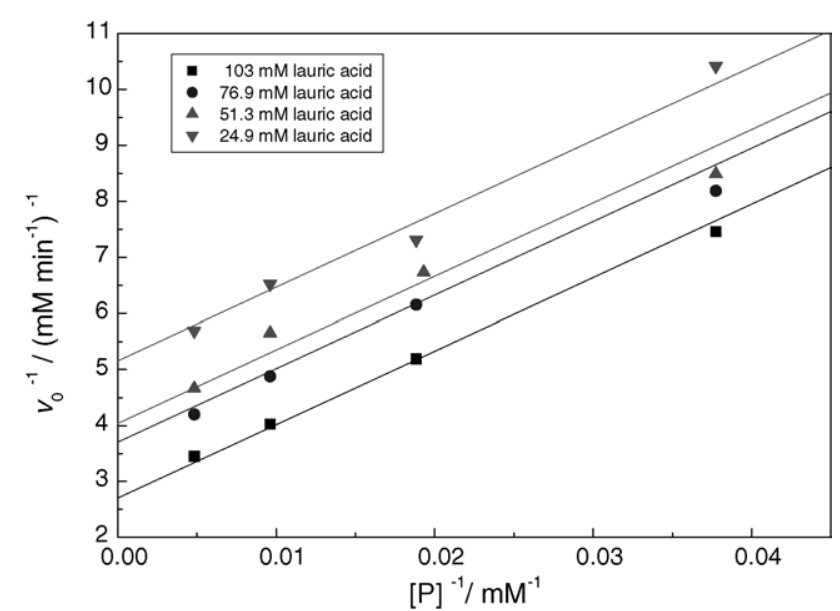

Fig. 5. Double reciprocal plot of the initial reaction velocity, $v_{0}$, as a function of the 1-propanol concentration, [P], at different fixed concentrations of lauric acid in $\mathrm{scCO}_{2}$ at 110 bar and $35^{\circ} \mathrm{C}$. 


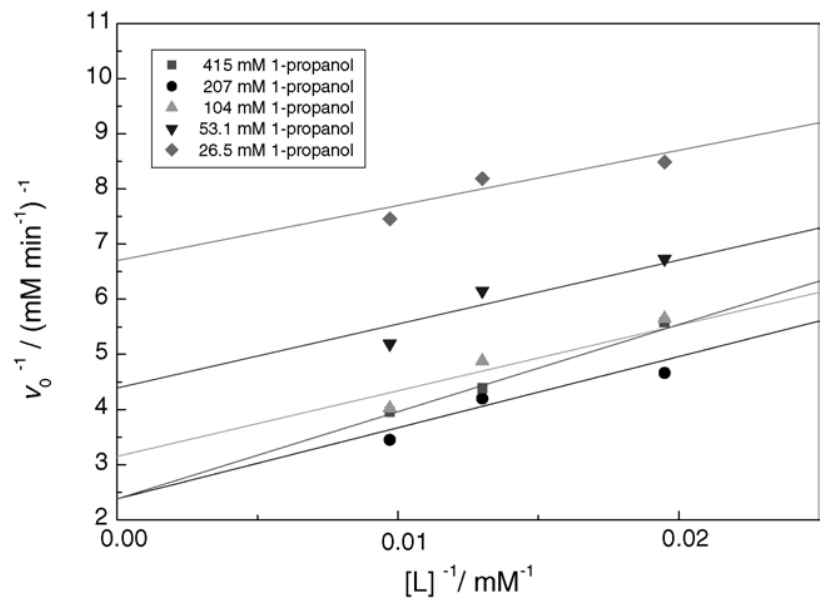

Fig. 6. Double reciprocal plot of the initial reaction velocity, $v_{0}$, as a function of the lauric acid concentration, [L], at different fixed concentrations of 1propanol in $\mathrm{scCO}_{2}$ at 110 bar and $35^{\circ} \mathrm{C}$.

alcohols as shown in Fig. 7. In order to avoid competition reactions with the internal alcohol of the microemulsion of the organogel, 2-propanol was used for the microemulsion formulation. This secondary alcohol cannot be converted by $\mathrm{CaL}$ under these conditions. It can be seen that in $\mathrm{scCO}_{2}$ there is an increase of the reaction rate from ethanol to 1butanol. This maximum is followed by a sharp decline and a slow increase towards the long chain alcohols. In isooctane the observed pattern is similar. Only the maximum is shifted from 1-butanol to 1-propanol.

In the case of examining the fatty acid chain length effect on the esterification of 1-propanol, the results (cf. Fig. 8) showed a diverse behavior in the two media. In $\mathrm{scCO}_{2}$, there is a tendency towards increasing reaction velocity with increasing number of carbon atoms, whereas in isooctane the initial rate decreases in the same direction.

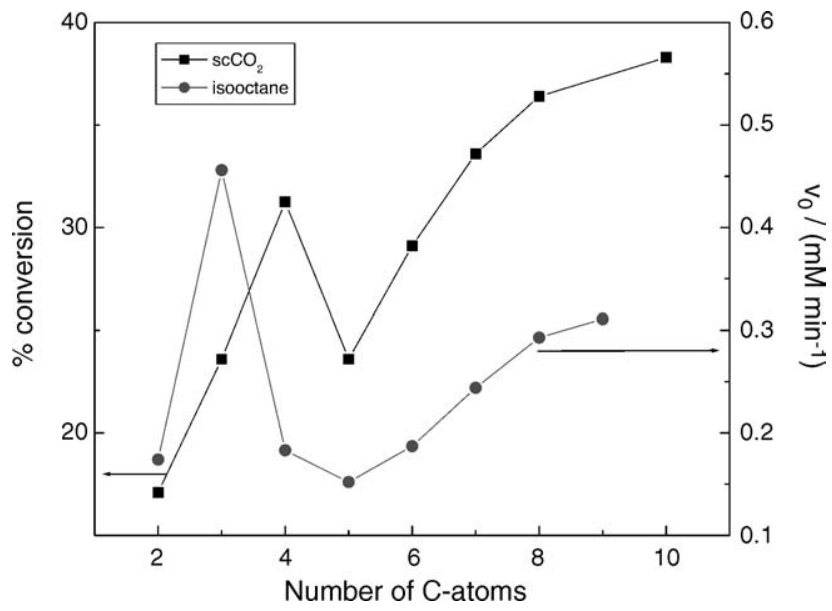

Fig. 7. Effect of the alcohol chain length on the conversion after $3 \mathrm{~h}$ reaction time in $\mathrm{scCO}_{2}\left(35^{\circ} \mathrm{C} ; 110 \mathrm{bar}\right)$ and on the initial rate, $v_{0}$, in isooctane $\left(35^{\circ} \mathrm{C}\right)$. Esterification of different primary alcohols $(100 \mathrm{mM}$ each) with $100 \mathrm{mM}$ lauric acid catalyzed by CaL immobilized in HPMC-containing lecithin MBG.

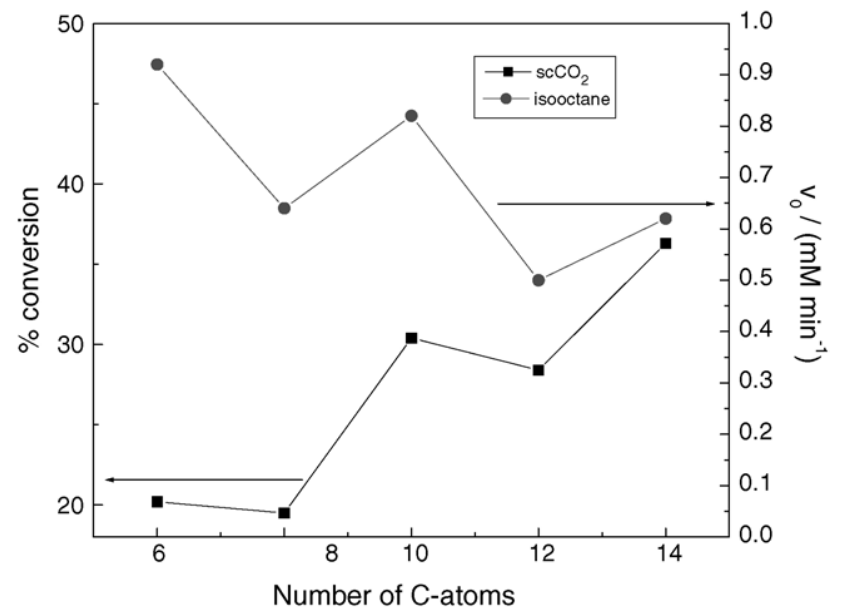

Fig. 8. Effect of the acid chain length on the conversion after $3 \mathrm{~h}$ reaction time in $\operatorname{scCO}_{2}\left(35^{\circ} \mathrm{C} ; 110 \mathrm{bar}\right)$ and on the initial rate, $v_{0}$, in isooctane $\left(35^{\circ} \mathrm{C}\right)$. Esterification of different acids (100 mM each) with $200 \mathrm{mM}$ 1-propanol catalyzed by $\mathrm{CaL}$ immobilized in HPMC-containing lecithin MBG.

\subsection{Effect of gel composition}

Fig. 9 shows the effect of changes of the gel composition on the initial rate of the esterification of lauric acid and 1propanol in both $\mathrm{scCO}_{2}(110 \mathrm{bar})$ and isooctane as solvent at $35^{\circ} \mathrm{C}$. As can be seen, an increase of the HPMC mass fraction, $\xi_{\text {HPMC }}$, and thus a decrease of the water content, $\xi_{\mathrm{H}_{2} \mathrm{O}}$, of the gel results in an increased initial reaction rate.

In addition, experiments on freezing and melting of water in HPMC gels of different biopolymer and thus different water concentrations were performed by DSC measurements on freshly prepared MBGs. A peak-analysis was accomplished with the DSC data and the amounts of different water types were estimated from the peak areas by using an equation for the temperature dependent heat of fusion for water derived from thermoporometry studies [34,35]. DSC measurements

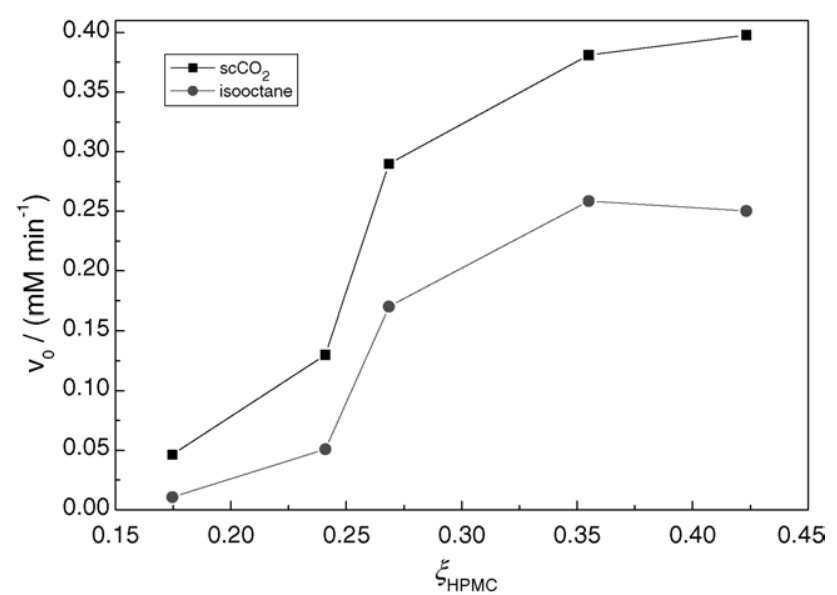

Fig. 9. Influence of the HPMC mass fraction, $\xi_{\text {HPMC }}$, on synthetic activity of $\mathrm{CaL}$ in lecithin-based MBGs containing $1.20 \mathrm{mg}$ enzyme. Esterification of $100 \mathrm{mM}$ lauric acid and $200 \mathrm{mM} 1$-propanol at $35^{\circ} \mathrm{C}_{\text {in } \mathrm{scCO}_{2}}$ and isooctane, respectively. 
Table 2

DSC measurements on HPMC-lecithin MBGs with increasing HPMC fraction, $\xi_{\mathrm{HPMC}}$, and thus decreasing water content, $\xi_{\mathrm{H}_{2} \mathrm{O}}$. Results from heating experiments starting from $-20{ }^{\circ} \mathrm{C}$ with a scan rate of $0.5 \mathrm{~K} \mathrm{~min}^{-1}$. Onset temperatures of the different water peaks and estimated fractions $\chi_{i}$ with respect to the total water amount in the gel matrix

\begin{tabular}{|c|c|c|c|c|c|c|c|}
\hline \multirow[t]{2}{*}{$\xi_{\text {HPMC }}$} & \multirow[t]{2}{*}{$\xi_{\mathrm{H}_{2} \mathrm{O}}$} & \multicolumn{2}{|c|}{$\begin{array}{l}\text { Bulk-like } \\
\text { water }\end{array}$} & \multicolumn{2}{|c|}{$\begin{array}{l}\text { Interfacial } \\
\text { water I }\end{array}$} & \multicolumn{2}{|c|}{$\begin{array}{l}\text { Interfacial } \\
\text { water II }\end{array}$} \\
\hline & & $\begin{array}{l}\text { Onset } \\
\left({ }^{\circ} \mathrm{C}\right)\end{array}$ & $\chi_{\mathrm{B}}$ & $\begin{array}{l}\text { Onset } \\
\left({ }^{\circ} \mathrm{C}\right)\end{array}$ & $\chi_{\mathrm{I}}$ & $\begin{array}{l}\text { Onset } \\
\left({ }^{\circ} \mathrm{C}\right)\end{array}$ & $\chi_{\mathrm{II}}$ \\
\hline 0.18 & 0.70 & -1.4 & 0.39 & -4.8 & 0.56 & - & - \\
\hline 0.27 & 0.53 & -2.2 & 0.26 & -6.7 & 0.47 & -13.9 & 0.15 \\
\hline 0.42 & 0.42 & - & - & -7.5 & 0.30 & -13.9 & 0.40 \\
\hline
\end{tabular}

on the pure lecithin microemulsions displayed no melting and freezing events in the studied temperature range.

Table 2 shows the results of the DSC analysis allowing the identification of three different states of water in the MBGs. The highest melting point at approximately $-2{ }^{\circ} \mathrm{C}$ can be assigned to bulk-like water which is free water with no or very weak interactions with the biopolymer. In addition, there are two different types of interfacial water with weaker (melting point of approximately -5 to $-7^{\circ} \mathrm{C}$; type I) and stronger (melting point approximately $-14^{\circ} \mathrm{C}$; type II) interactions with the polymer. The results compiled in Table 2 also hint at a fourth type of water in the gel matrix, as not all water is found by the DSC measurements. This water structure can be classified as non-freezable, bound water with the strongest polymer interactions of all water types.

\subsection{Biocatalyst reuse}

In order to get a first impression of the operational stability of the HMPC-lecithin gels containing CaL, they were used three consecutive times. Conversions per gram of gel after successive operational steps are shown in Fig. 10.

In the case of $\mathrm{scCO}_{2}$ a mass loss of gel occurs while pressure is released. The gel is partly flushed out and crushed into

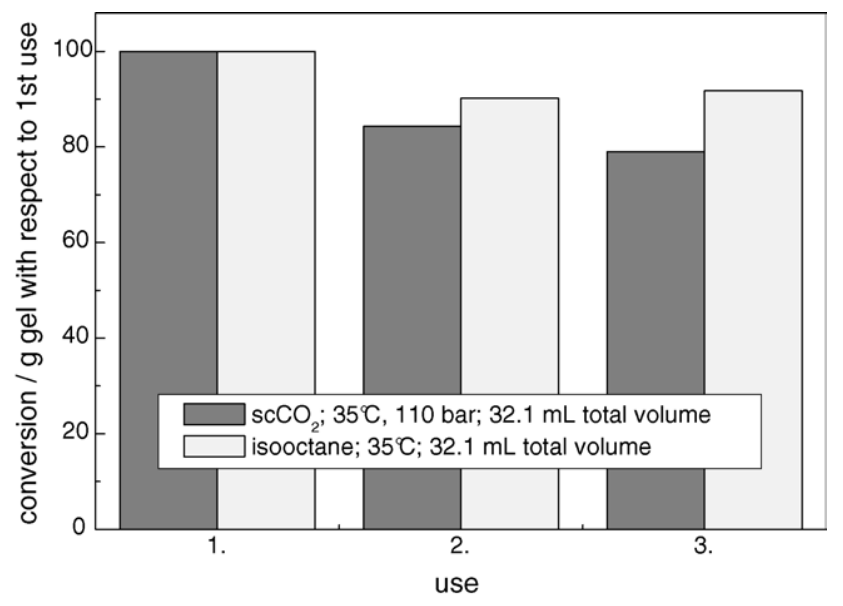

Fig. 10. Catalytic activity of CaL immobilized in a HPMC-lecithin MBG containing $1.20 \mathrm{mg}$ enzyme towards repeated synthesis of 1-propyl-laurate. Esterification of $100 \mathrm{mM}$ lauric acid and $200 \mathrm{mM}$ 1-propanol. smaller particles while it is pressed through the outlet of the cell resulting in smaller gel particles with each reuse. While the reaction products can easily be collected, the recovery of the gel is difficult and not complete at least with the highpressure apparatus used. The smaller the gel particles get, the less complete the gel recovery becomes. For the second use the available gel mass recovered was $83 \%$ of the initial gel mass, while for the third application it was just $45 \%$. After the second reuse the amount of gel was too small to start a fourth cycle.

\section{Discussion}

\subsection{Choice of system}

As Table 1 shows, HPMC and gelatin organogels based on both lecithin as well as AOT microemulsions are active in $\mathrm{CO}_{2}$. However, the gels are not completely inert in this medium under the particular reaction conditions chosen, as the solutions above the gels get turbid. This might indicate that some components are partially extracted from the gel. However, all gels exhibit catalytic activity.

The esterification between lauric acid and 1-propanol catalyzed by $\mathrm{CaL}$ in HPMC-lecithin organogel in $\mathrm{scCO}_{2}$ displayed initial rates higher than those in the reference system isooctane (cf. Fig. 9). In terms of conversion this reaction yielded $36.5 \%$ after $3 \mathrm{~h}$. Such a conversion can be considered to be quite high as compared to data reported on similar enzymatic reactions in $\mathrm{CO}_{2}$. Srivastava et al. [36] reported just $18 \%$ conversion for the reaction between myristic acid and ethanol in a batch reaction with a total volume of $6 \mathrm{~mL}$ using $10 \mathrm{mg}$ of crude lipase, an enzyme quantity which is eight times higher than in the present study. Steytler et al. [37] presented the esterification of lauric acid with butanol catalyzed by supported Candida lipase with a conversion of about $20 \%$ within $3 \mathrm{~h}$. Here again, the quantity of enzyme used is very high with $2.4 \mathrm{~g}$ in a reactor volume of $120 \mathrm{~mL}$. Furthermore, comparing to other studies $[38,39]$ concerning lipase-catalyzed reactions in $\mathrm{scCO}_{2}$, it seems that one of the main advantages of MBGs is the very small quantity of enzyme required for the efficient catalysis of such reactions (here, $1.20 \mathrm{mg}$ ).

The experiments with the phenolic acids HPA and HPP reveal a general restriction for the use of HPMC-based MBGs. Although these two acids can be catalytically esterified with 1-propanol in lecithin microemulsions containing CaL (data not shown), the use of HPMC-based MBGs is not possible as the acids are absorbed and can no longer be detected in the solutions above the gels. This can be directly observed for both acids in reactions with MBGs in isooctane with continuous sampling after predefined time-intervals, as the amount of acid detected by GC is continuously decreasing until complete absorption. Consequently, HPMC gels cannot be applied for esterification reactions of acids that show too strong interactions with the gel matrix. 
Furthermore, the HPMC-lecithin MBGs with $\mathrm{CaL}$ are capable to catalyze transesterification reactions in $\mathrm{scCO}_{2}$. However, tests with the gels in isooctane showed that not all esters might be suitable for catalytic transesterification with the MBG system investigated. For esters with additional functional groups or double bonds within the alkyl chain no conversion was observed after $3 \mathrm{~h}$ of reaction time. Similarly, the branched alcohols geraniol and nerol containing a double bond react very slowly.

\subsection{Effect of pressure}

The effect of pressure on enzymatic reactions in $\mathrm{scCO}_{2}$ has been the subject of investigation in several studies with contradictory results. Randolph et al. [40] reported a linear increase of the enzymatic oxidation rate of cholesterol with increasing pressure when using $\mathrm{scCO}_{2}$ saturated with the substrate. Miller et al. [41,42] working with lipases in $\mathrm{scCO}_{2}$ reported an increase of reaction rate with pressure as well. They both explained this fact by an increase of solubility of the substrates in the carbon dioxide. Similarly, Steytler et al. [37] observed an increase in the esterification rate of lauric acid with butanol catalyzed by an immobilized lipase in nearcritical $\mathrm{CO}_{2}$ when the pressure was increased. The authors attributed this effect to a higher adsorption of the synthesized ester on the enzyme bed as the solvent capacity of $\mathrm{CO}_{2}$ decreases with decreasing pressure.

In contrast, Vermuë et al. [43] observed a decline of the reaction rate in the transesterification of nonanol and ethyl acetate when raising the pressure in the system. The same observation was made by Erickson et al. [44], who studied the transesterification between trilaurin and palmitic acid catalyzed by immobilized lipase from Rhizopus arrhizus in supercritical ethane. They attributed the pressure effect to changes of the reactants' partitioning between the supercritical fluid and the vicinity of the enzyme. Likewise, Rantakylä and Aaltonen [39] reported a decrease of reaction rate with rising pressure in the enantioselective esterification of racemic ibuprofen with 1-propanol catalyzed by Lipozyme IM 20.

Finally, Ikushima et al. [45] and Nakaya et al. [46] observed even a peak of the initial rate at the vicinity of the critical point of carbon dioxide.

Recapitulating, Nakaya et al. [46] stated that at pressures above the critical region an increase of pressure results in an increase of reaction rate, if the amount of substrates is higher than the solubility limit, as this results in increasing substrate concentrations with pressure. On the other hand, an increase of pressure results in a decline of reaction velocity in the case of concentrations below the solubility limit.

In the present study, the reason for the decrease of the reaction rate with increasing pressure might be similar to the explanation given by Erickson et al. [44]. The rising pressure is accompanied by an increase of the solvating power of $\mathrm{scCO}_{2}$, i.e. the solubility of lauric acid and 1-propanol in the supercritical phase rises. Due to this solvation effect, the par- titioning of the substrates between the supercritical fluid, the oil phase of the microemulsion in the gel and the immediate vicinity of the enzyme is changed. The enzyme environment is depleted with regard to the substrates, which causes a decline in the reaction rate. As soon as the partitioning of the substrates is completely shifted to the supercritical phase, a further increase of pressure should no longer result in a further depletion in the enzyme environment, which means that the initial rate should no longer be affected by the rise of pressure. The plateau observed in Fig. 2 is in accordance to the later hypothesis.

\subsection{Kinetic analysis}

The results of the kinetic analysis (cf. Figs. 5 and 6) indicate that a Ping Pong Bi Bi mechanism with dead-end inhibition by alcoholic substrate (1-propanol) occurs in this system. The same mechanism has been proposed for esterification or transesterification reactions catalyzed by both free lipases in microemulsions [47] as well as immobilized lipases (lipozyme) in non-polar organic solvents [48] and $\mathrm{scCO}_{2}$ [49]. Furthermore, it has also been suggested for lipases immobilized in MBGs [13,24].

According to the Ping Pong Bi Bi mechanism model, the lipase reacts with lauric acid to form a lipase acid complex, which is then transformed to a carboxylic lipase by release of water. A subsequent nucleophilic attack of alcohol on this intermediate results finally in the regeneration of the enzyme and the release of ester. A possible explanation for the alcohol inhibitory effect might be that 1-propanol reacts with the free lipase, a dead-end complex is formed, and the lipase cannot further participate in the reaction. The general rate equation for this kind of mechanism [50] is shown in Eq. (1), where $v_{0}$ is the initial velocity, $v_{\max }$ is the maximum velocity under saturation conditions, $K_{\mathrm{m}}^{\mathrm{A}}$ and $K_{\mathrm{m}}^{\mathrm{B}}$ are the Michaelis-Menten constants for the acid and the alcohol, respectively, and $K_{\mathrm{i}}^{\mathrm{B}}$ is the inhibition constant for the alcohol.

$v_{0}=\frac{v_{\max }[\mathrm{A}][\mathrm{B}]}{K_{\mathrm{m}}^{\mathrm{A}}[\mathrm{B}]\left(1+\left([\mathrm{B}] / K_{\mathrm{i}}^{\mathrm{B}}\right)\right)+K_{\mathrm{m}}^{\mathrm{B}}[\mathrm{A}]+[\mathrm{A}][\mathrm{B}]}$

The kinetic constants were determined by fitting the experimental data to Eq. (1) by non-linear regression and values are given in Table 3. In Fig. 4, symbols represent experimental data, whereas lines represent the kinetic model according to Eq. (1).

Table 3

Apparent kinetic constants for $\mathrm{scCO}_{2}$ according to Eq. (1). Esterification of lauric acid and 1-propanol catalyzed by CaL immobilized in a HPMClecithin MBG containing $1.20 \mathrm{mg}$ enzyme at $35^{\circ} \mathrm{C}$ and 110 bar in $\mathrm{scCO}_{2}$. A and $\mathrm{B}$ stand for the substrates lauric acid and 1-propanol, respectively

\begin{tabular}{ll}
\hline Apparent kinetic constants & HPMC-lecithin MBG in $\mathrm{scCO}_{2}$ \\
\hline$K_{\mathrm{m}}^{\mathrm{A}}(\mathrm{mM})$ & $22.9 \pm 6.80$ \\
$K_{\mathrm{m}}^{\mathrm{B}}(\mathrm{mM})$ & $56.4 \pm 10.8$ \\
$K_{\mathrm{i}}^{\mathrm{B}}(\mathrm{mM})$ & $367 \pm 205$ \\
$v_{\max }\left(\mathrm{mM} \mathrm{min}{ }^{-1}\right)$ & $0.420 \pm 0.039$ \\
\hline
\end{tabular}


The determined kinetic constants represent apparent ones, as the esterification does not take place in a homogeneous medium and the constants are probably affected by internal diffusion, i.e. substrate transport from the surface of the organogel to the microenvironment of the enzyme. In spite of the unstirred solution, the influence of the diffusion within the solvent should be small because of the high diffusivity in supercritical fluids [51].

Kinetic analysis of the same reaction system performed in isooctane issued plots that likewise indicate a Ping Pong $\mathrm{Bi} \mathrm{Bi}$ mechanism. However, due to the poor reproducibility the fitting of these data according to Eq. (1) results in errors greater than the numerical values of the respective kinetic constants. Thus, a direct comparison between the kinetic constants in the two different solvents cannot be accurately drawn.

\subsection{Effect of substrate chain length}

Reactions of various alcohols in both media, indicated no significant differences regarding the effect of alcohol chain length on the initial rates in $\mathrm{scCO}_{2}$ and isooctane, respectively, except for the case of 1-propanol. It is known that the different partitioning of alcoholic substrates in various phases of the system influences the catalytic behavior of lipases in AOT or lecithin microemulsions [52]. Thus, differences in the reaction rates for different alcohols can be attributed to the diverse partitioning of the alcohols between the (organic) solvent and the microenvironment of the immobilized lipase.

Consequently, the observed maximum in the reaction rate for 1-butanol in $\mathrm{scCO}_{2}$ can be attributed to the high solubility of this alcohol in the vicinity of the enzyme displaying the good co-surfactant property of this alcohol. Similar observations have been made in other studies on the effect of alcohol chain length on lipase activity. Sawant and co-workers stated a maximum in the initial rate for 1-butanol for both immobilized M. miehei lipase [53] as well as for soluble Lipolase $100 \mathrm{~L}$ in a biphasic reaction system [54]. In addition, Delimitsou et al. [24] reported the same finding for M. miehei lipase immobilized on HPMC-containing AOT MBG at $25^{\circ} \mathrm{C}$.

However, in this study the maximum in isooctane is shifted to 1-propanol. A possible explanation might be that an exchange of the inner (2-propanol) and the outer (1-propanol) alcohol proceeds in isooctane leading to a higher concentration of the reactant in the microenvironment of the enzyme, whereas this substitution does not occur to the same extent in $\mathrm{scCO}_{2}$ hindering the external 1-propanol from reaching the enzyme. This would also explain the observed maximum for 1-butanol mentioned in a study on $M$. miehei lipase immobilized on HPMC-containing AOT MBG [24], a system that does not contain an internal alcohol in the microemulsion of the gel.

Investigations concerning the influence of acid chain length on the initial rate of esterifications catalyzed by lipases immobilized on MBGs have not yet been reported in the literature. So far, just the differences in the final yield of ester have been reported [11,21,23].

In the case of acids with different chain length, the behavior in $\mathrm{scCO}_{2}$ and isooctane is completely different. In $\mathrm{scCO}_{2}$, the initial rate increases with increasing chain length, whereas in isooctane there is a decline of the reaction rate towards longer acids. Again, this can be attributed to a different partitioning of the acids between the solvent and the microenvironment of the enzyme. The longer the chains of the acids become, the more alkane-like they behave, which results in an increasing solubility in isooctane and a decreasing solubility in $\mathrm{scCO}_{2}$. This means that in $\mathrm{scCO}_{2}$ the concentration of the acids in the vicinity of the enzyme increases with increasing chain length leading to higher reaction rates. In contrast, the surrounding of the enzyme is depleted, if the solvent is isooctane.

Furthermore, it seems that the reaction system consisting of the enzyme immobilized on the MBG prefers the acids with 6,10 and $14 \mathrm{C}$-atoms to the acids with 8 and $12 \mathrm{C}$-atoms, as the initial rates for the latter acids are lower compared to the former ones. Obviously, this is not affected by the change in the solvent as it can be seen from both curves in Fig. 8.

\subsection{Effect of gel composition}

Fig. 9 indicates an increase in the reaction rate with increasing HPMC mass fraction. The same has already been reported for the catalytic esterification of lauric acid and 1hexanol using agar- or HPMC-based organogels containing M. miehei lipase entrapped in an AOT microemulsion [24]. The effect was observed for both solvent-free reactions (1hexanol as solvent) as well as reactions carried out in isooctane. In addition, a similar behavior has been reported on the esterification of 1-propanol with lauric acid catalyzed by $R h i$ zomucor miehei as well as $C$. antarctica lipase in organogels formulated with lecithin microemulsions [23].

The different states of water in (hydro-)gels based on cellulose or cellulose derivatives have been the subject of investigations by many authors. A review was given by Ford and Mitchell [55]. The majority of authors discusses models of gel structures displaying three different states of water. These are generally bound water, free (unbound) water and weakly bound or interfacial water [55]. Taniguchi and Horigome [56] described four different states of water in cellulose acetate membranes, namely completely free water, free water interacting weakly with the polymer, bound water which can contain salts, and bound water which rejects salts.

The present DSC measurements on organogels also hint at four different states of water in a similar way as those mentioned above. It was found that the different water types of the organogel matrix depended on the HPMC mass fraction. The matrix of the gel with the highest water content shows bulk-like water and interfacial water I, whereas the gel with the highest HPMC fraction contains just the two types of interfacial water. The gel with medium composition displays all three different water types in lower concentration with re- 
spect to the two gels mentioned before. The initial rates of the enzymatic reaction correlate with this change in water structure: increasing interfacial water II and thus decreasing bulk-like water content leads to an increase of the reaction rate. A possible explanation for this behavior might be that the diffusion of the reactants to the enzyme located in the microemulsion through the gel matrix is less impeded by weaker interactions with the more strongly bound and thus more apolar water. A similar conclusion was drawn for changes in the semipermeability of cellulose membranes [56] and the modulation of drug release from cellulose matrix tablets, where the interactions between drugs and the hydrating gel layer around the tablets seem to be at least partly responsible for changes in the drug release [55].

Another explanation might be a change of the total surface area of the gels. Although all gels were cut into several pellets of approximately equal size, the gels differ quite strongly from each other in the outward appearance. HPMC gels with high water content are cohesive and are in a way similar to gelatin-based MBGs. In contrast, the gels with high HPMC content appear to consist of many loose gel particles sticking together. Hence, the change from low to high HPMC fraction might lead to an increase of the total surface area of the gels and might thus minimize diffusion distances in the gel.

The influence of the surface area of MBGs on the reaction rate has first been observed by Jenta and co-workers [12]. They reported that granulated gelatin-based gels with an AOT microemulsion containing Chromobacterium viscosum lipase behave differently from pelleted MBGs of the same composition. The observed initial rates were generally higher for the granulated gels having a higher surface area per unit volume than the pellets. They attributed this effect to the importance of diffusion distances. Furthermore, Hedström et al. [57] conducted a study on the influence of the gel surface area on the initial rate of gelatin AOT MBGs with $C$. antarctica lipase and were able to show that the extrapolated initial rate of hypothetical pellet gels with infinitely large areas are in good agreement with those obtained for granulated MBGs representing gels where diffusion distances are minimized.

\subsection{Biocatalyst reuse}

The operational stability of an immobilized enzyme, i.e. the ability to reuse it, is an important parameter determining the economic viability of a biocatalytic process. As can be seen in Fig. 10, the lipase activity in both solvents is quite well preserved. It should be noted that in the case of $\mathrm{scCO}_{2}$ the mass loss due to the sudden depressurizing of the highpressure cell, leads by itself to a decline of activity as the total enzyme concentration in the cell decreases. Nevertheless, the slight decrease of activity is comparable in both solvents, i.e. $\mathrm{scCO}_{2}$ obviously does not negatively influence the operational stability of the HPMC gels containing lipase.

However, due to the limited number of reuses the experiments can just give preliminary and rough initial insight to the operational stability of the CaL immobilized on the HPMC- lecithin MBG. In order to get a further impression of the reusability of the organogels, the number of reuses should be increased and the MBGs should also be investigated in a continuous reaction-separation process. This seems a realistic scenario for a future scale up of the MBG use in $\mathrm{scCO}_{2}$ in which no depressurizing steps would deteriorate the biocatalyst. At the present stage of the high-pressure apparatus these experiments could not be carried out.

\section{Conclusion}

The present study demonstrates that microemulsion-based organogels formulated with HPMC and gelatin can be used as solid-phase catalysts in liquid and supercritical carbon dioxide as external solvents for substrates. Lipase hosted in MBGs retains its ability to catalyze esterification reactions of fatty acids and alcohols and transesterifications in these media. Furthermore, the initial rates of the model esterification reaction of lauric acid and 1-propanol are higher in $\mathrm{scCO}_{2}$ than in the corresponding isooctane system.

With a focus on HPMC-based organogels formulated with lecithin microemulsions containing $C$. antarctica lipase, it has been shown that the mechanism of the chosen model esterification of lauric acid and 1-propanol seems to be of the Ping Pong Bi Bi type with dead-end inhibition by excess of alcohol. In addition, the effect of pressure on the initial rate of the esterification displayed a similar behavior as described in literature for reactant concentrations below saturation. The influence of alcohol and acid chain length on the initial rate showed significant differences between isooctane and $\mathrm{scCO}_{2}$. This can be attributed to different partitioning of the reactants in the two solvents. In contrast, the effect of gel composition on the reaction rate is similar in both solvents. Further, DSC measurements on the gels of different composition gave additional insight into the observed increase of reaction velocity with increasing polymer fraction.

Biocatalyst reuse experiments in $\mathrm{scCO}_{2}$ showed that the slight decrease of activity is similar to that observed in isooctane. Provided that continuous reaction-separation processes lead to similar conclusions, the combination of MBGs with the solvent $\mathrm{scCO}_{2}$ represents a promising "green" reaction system for bioconversions. It should be noted that in such a combination the amount of less green substances such as the constituents of the microemulsion and the enzyme is very small.

In summary, the potential of reusable MBGs in biocatalytic processes involving enzymes with high biotechnological value can be combined with the tunable solvent and solvation properties of $\mathrm{scCO}_{2}$ and hence with the superior reaction-separation processes based on supercritical fluids.

\section{References}

[1] P.T. Anastas, J.C. Warner, Green Chemistry: Theory and Practice, Oxford University Press, Oxford, 1998. 
[2] J. Clark, D. Macquarrie (Eds.), Handbook of Green Chemistry and Technology, Blackwell Science, Oxford, 2002.

[3] A. Ballesteros, U. Bornscheuer, A. Capewell, D. Combes, J. Condoret, K. Koenig, F.N. Kolisis, A. Marty, U. Menge, T. Scheper, H. Stamatis, A. Xenakis, Review article: Enzymes in non-conventional phases, Biocatal. Biotransform. 13 (1995) 1-42.

[4] G. Carrea, S. Riva, Properties and synthetic applications of enzymes in organic solvents, Angew. Chem. Int. Ed. 39 (2000) 2226-2254.

[5] H. Stamatis, A. Xenakis, F.N. Kolisis, Bioorganic reactions in microemulsions: the case of lipases, Biotechnol. Adv. 17 (1999) 293-318.

[6] G. Haering, P.L. Luisi, Hydrocarbon gels from water-in-oil microemulsions, J. Phys. Chem. 90 (1986) 5892-5895.

[7] C. Quellet, H.F. Eicke, Mutual gelation of gelatin and water-in-oil microemulsions, Chimia 40 (1986) 233-238.

[8] C. Quellet, H.F. Eicke, Some comments on the gelation of gelatin containing water/oil microemulsions, J. Phys. Chem. 91 (1987) 42114212.

[9] P.J. Atkinson, B.H. Robinson, A.M. Howe, R.K. Heenan, Structure and stability of microemulsion-based organo-gels, J. Chem. Soc., Faraday Trans. 87 (1991) 3389-3397.

[10] C. Quellet, H.-F. Eicke, W. Sager, Formation of microemulsion-based gelatin gels, J. Phys. Chem. 95 (1991) 5642-5655.

[11] G.D. Rees, M.D.G. Nascimento, T.R.J. Jenta, B.H. Robinson, Reverse enzyme synthesis in microemulsion-based organogels, Biochim. Biophys. Acta 1073 (1991) 493-501.

[12] T.R. Jenta, G. Batts, G.D. Rees, B.H. Robinson, Biocatalysis using gelatin microemulsion-based organogels containing immobilized chromobacterium viscosum lipase, Biotechnol. Bioeng. 53 (1997) 121-131.

[13] T.R. Jenta, G. Batts, G.D. Rees, B.H. Robinson, Kinetic studies of Chromobacterium viscosum lipase in AOT water-in-oil microemulsions and gelatin microemulsion-based organogels, Biotechnol. Bioeng. 54 (1997) 416-427.

[14] S. Backlund, F. Eriksson, L.T. Kanerva, M. Rantala, Selective enzymic reactions using microemulsion-based gels, Colloid. Surf. B 4 (1995) 121-127.

[15] S. Backlund, F. Eriksson, S. Karlsson, G. Lundsten, Enzymic esterification and phase behavior in ionic microemulsions with different alcohols, Colloid Polym. Sci. 273 (1995) 533-588.

[16] G.D. Rees, B.H. Robinson, G.R. Stephenson, Preparative-scale kinetic resolutions catalyzed by microbial lipases immobilized in AOTstabilized microemulsion-based organogels: cryoenzymology as a tool for improving enantioselectivity, Biochim. Biophys. Acta 1259 (1995) $73-81$.

[17] K. Nagayama, K. Tada, K. Naoe, M. Imai, Rhizopus delemar lipase in microemulsion-based organogels: reactivity and rate-limiting study, Biocatal. Biotransform. 21 (2003) 321-324.

[18] K. Nagayama, N. Yamasaki, M. Imai, Fatty acid esterification catalyzed by Candida rugosa lipase in lecithin microemulsion-based organogels, Biochem. Eng. J. 12 (2002) 231-236.

[19] N.W. Fadnavis, R. Luke Babu, G. Sheelu, A. Deshpande, 'Gelozymes' in organic synthesis: synthesis of enantiomerically pure $(S)$-2-hydroxy(3-phenoxy)phenylacetonitrile with lipase immobilized in a gelatin matrix, Tetrahedron Asymm. 11 (2000) 3303-3309.

[20] K. Soni, D. Madamwar, Ester synthesis by lipase immobilized on silica and microemulsion based organogels (MBGs), Process Biochem. 36 (2001) 607-611

[21] G. Zhou, G. Li, J. Xu, Q. Sheng, Kinetic studies of lipase-catalyzed esterification in water-in-oil microemulsions and the catalytic behavior of immobilized lipase in MBGs, Colloid. Surf. A 194 (2001) 41-47.

[22] H. Stamatis, A. Xenakis, Biocatalysis using microemulsion-based polymer gels containing lipase, J. Mol. Catal. B: Enzyme 6 (1999) 399-406.

[23] A. Pastou, H. Stamatis, A. Xenakis, Microemulsion-based organogels containing lipase: application in the synthesis of esters, Prog. Colloid Polym. Sci. 115 (2000) 192-195.

[24] C. Delimitsou, M. Zoumpanioti, A. Xenakis, H. Stamatis, Activity and stability studies of Mucor miehei lipase immobilized in novel microemulsion-based organogels, Biocatal. Biotransform. 20 (2002) 319-327.

[25] E.W. Lemmon, M.O. McLinden, D.G. Friend, Thermophysical properties of fluid systems, in: P.J. Linstrom, W.G. Mallard (Eds.), NIST Chemistry Webbook, NIST Standard Reference Database 69, National Institute of Standards and Technology, Gaithersburg MD, März, 2003.

[26] S.L. Wells, J. DeSimone, $\mathrm{CO}_{2}$ Technology platform: an important tool for environmental problem solving, Angew. Chem. Int. Ed. 40 (2001) 518-527.

[27] T.W. Randolph, H.W. Blanch, J.M. Prausnitz, C.R. Wilke, Enzymic catalysis in a supercritical fluid, Biotechnol. Lett. 7 (1985) 325-328.

[28] J.D. Holmes, D.C. Steytler, G.D. Rees, B.H. Robinson, Bioconversions in a water-in- $\mathrm{CO}_{2}$ microemulsion, Langmuir 14 (1998) 6371-6376.

[29] G.C. Irvin Jr., V.T. John, Materials synthesis via water-in-dense $\mathrm{CO}_{2}$ microemulsions: a novel reaction medium, Proc. NOBBCChE 25 (1998) 59-67.

[30] M.A. Kane, G.A. Baker, S. Pandey, F.V. Bright, Performance of cholesterol oxidase sequestered within reverse micelles formed in supercritical carbon dioxide, Langmuir 16 (2000) 4901-4905.

[31] M. Perrut, Enzymic reactions in supercritical carbon dioxide, Colloque INSERM 224 (1992) 401-410.

[32] T. Hartmann, E. Schwabe, T. Scheper, D. Combes, Enzymatic reactions in supercritical carbon dioxide, in: R.N. Patel (Ed.), Stereoselective Biocatalysis, Marcel Dekker, New York, 2000, pp. 799-838.

[33] R.S. Oakes, A.A. Clifford, C.M. Rayner, The use of supercritical fluids in synthetic organic chemistry, J. Chem. Soc. Perkin Trans. 1 (2001) 917-941.

[34] M. Brun, A. Lallemand, J.-F. Quinson, C. Eyraud, A new method for the simultaneous determination of the size and the shape of pores: the thermoporometry, Thermochim. Acta 21 (1977) 59-88.

[35] J.N. Hay, P.R. Laity, Observations of water migration during thermoporometry studies of cellulose films, Polymer 41 (2000) 6171-6180.

[36] S. Srivastava, G. Madras, J. Modak, Esterification of myristic acid in supercritical carbon dioxide, J. Supercrit. Fluids 27 (2003) 55-64.

[37] D.C. Steytler, P.S. Moulson, J. Reynolds, Biotransformations in nearcritical carbon dioxide, Enzyme Microb. Technol. 13 (1991) 221226.

[38] A. Marty, D. Combes, J.S. Condoret, Fatty acid esterification in supercritical carbon dioxide, Progress Biotechnol. 8 (1992) 425-432.

[39] M. Rantakylä, O. Aaltonen, Enantioselective esterification of ibuprofen in supercritical carbon dioxide by immobilized lipase, Biotechnol. Lett. 16 (1994) 825-830.

[40] T.W. Randolph, H.W. Blanch, J.M. Prausnitz, Enzyme-catalyzed oxidation of cholesterol in supercritical carbon dioxide, AIChE J. 34 (1988) 1354-1360

[41] D.A. Miller, H.W. Blanch, J.M. Prausnitz, Enzymic interesterification of triglycerides in supercritical carbon dioxide, Ann. N.Y. Acad. Sci. 613 (1990) 534-537.

[42] D.A. Miller, H.W. Blanch, J.M. Prausnitz, Enzyme-catalyzed interesterification of triglycerides in supercritical carbon dioxide, Ind. Eng. Chem. Res. 30 (1991) 939-946.

[43] M.H. Vermuë, J. Tramper, J.P.J. De Jong, W.H.M. Oostrom, Enzymic transesterification in near-critical carbon dioxide: effect of pressure, Hildebrand solubility parameter and water content, Enzyme Microb. Technol. 14 (1992) 649-655.

[44] J.C. Erickson, P. Schyns, C.L. Cooney, Effect of pressure on an enzymic reaction in a supercritical fluid, AIChE J. 36 (1990) 299-301.

[45] Y. Ikushima, N. Saito, M. Arai, Promotion of lipase-catalyzed esterification of $N$-valeric acid and citronellol in supercritical carbon dioxide in the near-critical region, J. Chem. Eng. Jpn. 29 (1996) 551-553.

[46] H. Nakaya, O. Miyawaki, K. Nakamura, Transesterification between triolein and stearic acid catalyzed by lipase in $\mathrm{CO}_{2}$ at various pressures, Biotechnol. Tech. 12 (1998) 881-884.

[47] H. Stamatis, A. Xenakis, U. Menge, F.N. Kolisis, Kinetic study of lipase catalyzed esterification reactions in water-in-oil microemulsions, Biotechnol. Bioeng. 42 (1993) 931-937. 
[48] W. Chulalaksananukul, J.S. Condoret, D. Combes, Geranyl acetate synthesis by lipase-catalyzed transesterification in supercritical carbon dioxide, Enzyme Microb. Technol. 15 (1993) 691-698.

[49] A. Marty, W. Chulalaksananukul, R.M. Willemot, J.S. Condoret, Kinetics of lipase-catalyzed esterification in supercritical carbon dioxide, Biotechnol. Bioeng. 39 (1992) 273-280.

[50] I.H. Segel, Enzyme Kinetics-Behavior and Analysis of Rapid Equilibrium and Steady-State Enzyme Systems, 2nd ed., Wiley, New York, 1993.

[51] P.G. Jessop, W. Leitner (Eds.), Chemical Synthesis Using Supercritical Fluids, Wiley-VCH, Weinheim, 1999.

[52] H. Stamatis, A. Xenakis, M. Provelegiou, F.N. Kolisis, Esterification reactions catalyzed by lipases in microemulsions: the role of enzyme localization in relation to its selectivity, Biotechnol. Bioeng. 42 (1993) 103-110.
[53] N.N. Gandhi, S.B. Sawant, J.B. Joshi, Specificity of a lipase in ester synthesis: effect of alcohol, Biotechnol. Prog. 11 (1995) 282287.

[54] M.S. Shintre, R.S. Ghadge, S.B. Sawant, Kinetics of esterification of lauric acid with fatty alcohols by lipase: effect of fatty alcohol, J. Chem. Technol. Biotechnol. 77 (2002) 1114-1121.

[55] J.L. Ford, K. Mitchell, Thermal analysis of gels and matrix tablets containing cellulose ethers, Thermochim. Acta 248 (1995) 329345.

[56] Y. Taniguchi, S. Horigome, The states of water in cellulose acetate membranes, J. Appl. Polym. Sci. 19 (1975) 2743-2748.

[57] G. Hedström, S. Backlund, F. Eriksson, Influence of diffusion on the kinetics of an enzyme-catalyzed reaction in gelatin-based gels, J. Colloid Interface Sci. 239 (2001) 190-195. 